Artikel Penelitian

\title{
Analisis Implementasi Penemuan Pasien TB Paru dalam Program Penanggulangan TB Paru di Puskesmas Balai Selasa
}

\author{
Deri Zarwita ${ }^{1}$, Rosfita Rasyid ${ }^{2}$, Abdiana ${ }^{2}$
}

\begin{abstract}
Abstrak
Keberhasilan penanggulangan TB Paru di Indonesia ditentukan melalui tiga indikator yaitu Case Notification Rate (CNR), Case Detection Rate (CDR) dan Succes Rate. Capaian pada tahun 2015 dan tahun 2016 di Propinsi Sumatera Barat masih jauh dari target Standar Pelayanan Minimal (SPM). Tahun 2017 Puskesmas Balai Selasa penemuan kasus terendah sebanyak 18 kasus. Tujuan: Menganalisis penemuan pasien TB Paru dalam penanggulangan TB di Puskesmas Balai Selasa Kabupaten Pesisir Selatan. Metode: Penelitian ini dilakukan pada bulan Agustus 2018 sampai April 2019 dengan metode kualitatif. Pengumpulan data primer didapatkan dari wawancara mendalam, Focus Group Discussion (FGD), dan observasi. Informan dalam penelitian ini berjumlah 13 orang dan peserta FGD sebanyak 20 orang. Hasil: Kebijakan yang dipakai dalam penemuan penderita TB paru adalah kebijakan pusat dengan strategi DOTS, namun belum disosialisasikan kepada semua tenaga kesehatan. Tenaga pelaksana di puskesmas mencukupi secara kuantitas dan kualitas, hanya koordinator TB masih diberikan tugas rangkap, dana penemuan penderita TB masih kurang untuk kegiatan sweeping, sarana untuk pemeriksaan dahak belum ada di Puskesmas Balai Selasa. Penemuan penderita TB belum direncanakan secara terinci di dalam Plan Of Acion (POA), pelaksanaan penemuan penderita TB masih bersifat pasif, monitoring dan evaluasi belum dilakukan secara maksimal di puskesmas. Simpulan: Pelaksanaan penemuan pasien TB di Puskesmas Balai Selasa masih belum optimal dan cakupan penemuan penderita juga masih rendah.
\end{abstract}

Kata kunci: TB paru, penemuan, penanggulangan, stigma

\begin{abstract}
The success of controlling pulmonary TB in Indonesia is determined by: Case Notification Rate, Case Detection Rate and Success Rate. Achievements in 2015 and 2016, West Sumatra Province are still far from the Minimum Service Standart target. In 2017, the Balai Selasa Health Centers found the lowest number of cases of eighteen cases. Objectives: To analyzed the findings of patients with pulmonary Tuberculosis (TB) in TB control at the Balai Selasa Health Centers in South Coastal District. Methods: This research was conducted in August 2018 to April 2019 with qualitative methods. Primary data collection was obtained from in-depth interviews, Focus Group Discussion and observation. The informants were thirteen people and twenty FGD participants. Results: The policy used in the discovery of pulmonary TB sufferers was central policy with the Directly Observed Treatment Short-course Strategy (DOTS), but it has not been socialized to all health workers. Implementing staff at the Community Health Centers were sufficient in quantity and quality, only TB coordinators are still given multiple assignments, funds for finding $T B$ sufferers were still lacking for sweeping activities, facilities for sputum examinations were not available. The discovery of TB sufferers has not been planned in detail in Plan Of Action, the implementation of the discovery of TB patients is still passive, monitoring and evaluation have not been carried out maximally at the Community Health Centers.
\end{abstract} Conclusions: The implementation of TB findings is still not optimal and coverage of sufferers' discoveries is low. Keywords: pulmonary TB, discovery, prevention, stigma 
Affiliasi penulis: 1. Puskesmas Balai Selasa Kabupaten Pesisir Selatan. 2. Bagian IImu Kesehatan Masyarakat Fakultas Kedokteran Universitas Andalas Padang.

Korespondensi: Deri Zarwita, E-mail : derizarwita@yahoo.co.id, Hp : 081363042525

\section{PENDAHULUAN}

Tuberculosis (TB) paru merupakan penyakit infeksi menular langsung yang disebabkan oleh Mycobacterium tuberculosis. World Health Organization (WHO) memperkirakan antara tahun 2002-2020 akan ada sekitar satu miliar manusia terinfeksi TB Paru, jika dihitung pertambahan jumlah pasien TB Paru, akan meninggal setiap tahun. Selain itu, 1/3 penduduk dunia telah terinfeksi kuman tuberculosis dan 9,6 juta orang sakit karena TB Paru, 1,5 Juta orang meninggal karena TB Paru. ${ }^{1}$

Badan kesehatan dunia mendefinisikan negara dengan beban tinggi untuk TB Paru berdasarkan tiga indikator yaitu TB Paru, TB/HIV dan Multidrug Resistant-Tuberkulosis (MDR-TB). Terdapat 48 negara yang masuk dalam daftar tersebut. Satu negara dapat masuk salah satu daftar atau keduanya bahkan bisa ketiganya. Indonesia bersama 13 negara lain masuk dalam daftar High Burden Country (HBC) untuk ketiga indikator tersebut, artinya Indonesia memiliki permasalahan besar menghadapi penyakit TB Paru. ${ }^{2}$

Pada tahun 2014, kasus baru TB Paru di Indonesia sebanyak 420.994. Berdasarkan prevalensi tuberkulosis, prevalensi pada laki-laki 3 kali lebih tinggi dibandingkan perempuan. Berdasarkan survei prevalensi tuberculosis 2013-2014, prevalensi TB Paru dengan konfirmasi bakteriologis di Indonesia sebesar 759 per 100.000 penduduk berumur 15 tahun keatas dan prevalensi TB Paru BTA positif sebesar 257 per 100.000 penduduk berumur 15 tahun keatas. ${ }^{3}$

Pemberantasan penyakit TB Paru di Indonesia termasuk salah satu prioritas nasional untuk program pengendalian penyakit karena juga berdampak luas terhadap kualitas hidup dan ekonomi. ${ }^{4}$ Kondisi tersebut mengakibatkan pemerintah Indonesia menetapkan suatu pedoman pengendalian tuberculosis berbadan hukum. Pengendalian penyakit tuberculosis di Indonesia diatur dalam Keputusan Menteri Kesehatan RI 364/MenKes/SK/V/2009 tentang Pedoman Penanggulangan Tuberculosis. ${ }^{5}$
Keberhasilan penanggulangan TB Paru membutuhkan indikator-indikator sebagai bahan evaluasi dan monitoring. Indikator itu yaitu Case Notification Rate (CNR), Case Detection Rate (CDR) dan Succes Rate. Pada tahun 2017 pemerintah menetapkan CNR yang harus dicapai oleh $85 \%$, untuk CDR target yang harus dicapai adalah $70 \%$ dan untuk Succes Rate atau angka kesembuhan yang harus dicapai adalah $88 \%{ }^{2}$

Case Detection Rate (CDR) sebagai salah satu indikator pengendalian TB Paru, yaitu proporsi jumlah pasien baru BTA (+) yang ditemukan dan diobati terhadap jumlah pasien baru BTA (+) yang diperkirakan ada diwilayah tersebut. Pada tahun 2014, penemuan kasus TB Paru BTA positif (CDR) di Indonesia sebanyak 176.677 kasus. Menurun bila dibandingkan kasus baru BTA (+) yang ditemukan tahun 2013 yang sebesar 196.310 kasus. Jumlah kasus tertinggi yang dilaporkan terdapat di provinsi dengan jumlah penduduk yang besar yaitu Jawa Barat, Jawa Timur, dan Jawa Tengah. Kasus baru BTA+ di tiga provinsi tersebut sebesar $40 \%$ dari jumlah seluruh kasus baru di Indonesia. ${ }^{6}$

Provinsi Sumatera Barat pada tahun 2016, capaian penemuan penderita TB Paru BTA positif yaitu $38 \%$, angka ini dibawah target $36,7 \%{ }^{7}$ Berdasarkan Laporan tahunan Dinas Kesehatan Kabupaten Pesisir Selatan tahun 2017 angka penemuan pasien TB paru BTA (+) dari 18 Puskesmas yang ada terdapat di Pesisisr Selatan, kasus yang paling banyak ditemukan di Puskesmas Air haji sebanyak 55 kasus, Puskesmas dengan penemuan kasus terendah yaitu Puskesmas Balai Selasa sebanyak 18 kasus. Sedangkan untuk kasus kematian di Puskesmas Balai Selasa selama tahun 2017 terdapat 5 orang pasien TB Paru yang meninggal. ${ }^{8}$

Penemuan Pasien TB paru di Puskesmas Balai Selasa mengalami penurunan dari tahun 2015 sampai tahun 2017, dimana pada tahun 2015 penemuan kasus penderita BTA + (CDR) sebesar 48,9\%, dan mengalami penurunan di tahun 2016 menjadi 36\% dan meningkat di tahun 2017 menjadi $46 \%$ tetapi itu tetap masih dibawah target $70 \%{ }^{9}$

Banyak hal yang menyebabkan rendahnya capaian penemuan penderita TB Paru di Puskesmas Balai Selasa. Berdasarkan hasil penelitian awal yang 
dilakukan melalui wawancara mendalam, terhadap 10 orang penderita TB paru di Puskesmas Balai Selasa, diketahui bahwa $30 \%$ penderita merasa informasi tentang penyakit TB paru belum cukup mereka dapatkan, 30\% lagi mengeluhkan pelayanan TB Paru, dan $20 \%$ tidak puas dengan lamanya waktu tunggu saat melakukan pemeriksaan atau mendapat hasil pemeriksaan, serta $20 \%$ menyatakan keengganan untuk memeriksakan diri saat mengalami batuk selama 2 minggu karena menganggap itu tidak berbahaya.

Penelitian yang dilakukan oleh Rosmila et al (2014) menyebutkan faktor lain yang bisa menjadi penyebab rendahnya penemuan penderita TB Paru adalah rasa malu penderita TB Paru untuk memeriksakan diri ke fasilitas kesehatan. ${ }^{10}$ Survei pendahuluan juga dilakukan dengan mewawancarai petugas pemegang program TB Paru di Puskesmas Balai Selasa, dan didapatkan informasi bahwa penyebab rendahnya temuan penderita TB paru di puskesmas adalah penderita malas memeriksakan diri ke puskesmas karena masih menyukai dan percaya pada pengobatan secara tradisional atau berobat ke dukun saja, disamping itu masih kurangnya rujukan dari bidan di Poskesri atau di Polindes.

Penelitian yang dilakukan oleh Abraham (2018) menyatakan jika masalah sumber daya menjadi salah satu masalah dalam hal penemuan pasien TB paru, dimana masih kurangnya ketersediaan tenaga terlatih dalam program pengendalian TB paru di Puskesmas. $^{11}$ Keberhasilan suatu implementasi kebijakan akan ditentukan oleh beberapa variabel yaitu komunikasi, sumber daya, disposisi dan struktur birokrasi. $^{12}$

Disposisi atau pelimpahan tanggung jawab juga menjadi suatu permasalahan, karena tugas rangkap yang dimiliki oleh pemegang program TB paru puskesmas mengakibatkan petugas mengabaikan tugas dengan membiarkan pemeriksaan dahak yang harusnya diberikan kepada petugas analisis justru dilakukan oleh tenaga kesehatan lainnya yang tidak memiliki kompetensi, tidak optimalnya penemuan kasus juga disebabkan oleh petugas TB Paru yang tidak memahami prosedur dan hanya menunggu penderita TB Paru datang ke puskesmas.
Penelitian yang dilakukan Aboy (2013) mengenai implementasi program penanggulangan Tuberculosis di Puskesmas Kampung Dalam Kota Pontianak menyatakan bahwa sebagian besar perawat belum memahami sepenuhnya prosedur penanggulangan dan kurang mendapatkan pelatihan serta sistem pelaporan yang belum maksimal, akibatnya kegiatan pelayanan terhadap penderita TB Paru menjadi terhambat. ${ }^{13}$

Berdasarkan hal diatas, maka penelitian ini bertujuan untuk mengetahui implementasi penemuan pasien TB Paru dalam program penanggulangan TB Paru di Puskesmas Balai Salasa Kabupaten Pesisir Selatan.

\section{METODE}

Penelitian ini menggunakan pendekatan kualitatif. Pengumpulan data dilakukan pada bulan Agustus 2018 sampai dengan April 2019 di Dinas Kesehatan Kabupaten Pesisir Selatan dan Puskesmas Balai Selasa Kabupaten Pesisir Selatan.

Data yang didapatkan dalam penelitian ini berasal dari wawancara mendalam, Focus Group Discussion (FGD), observasi, dan telaah dokumen. Informan wawancara mendalam berjumlah 13 orang yaitu Kepala Dinas Kesehatan Kabupaten Pesisir Selatan, penanggung jawab program TB dinkes, Kepala Puskesmas Balai Selasa, penanggung jawab program TB Puskesmas, petugas labor, camat, tokoh masyarakat, 2 orang keluarga penderita, dan 4 orang penderita TB. Informan dalam FGD yaitu 20 orang bidan. Teknik penentuan informan yang digunakan adalah metode purposive sampling. Analisis data dilakukan menggunakan metode triagulasi teknik atau metode dan triagulasi sumber. Langkah dalam menganalisis data terdiri dari mereduksi data, menyajikan data, penarikan kesimpulan dan verifikasi.

\section{HASIL}

Berdasarkan hasil penelitian didapatkan bahwa kebijakan yang dipakai Dinas Kesehatan dan Puskesmas yang ada di Pesisir Selatan masih mengacu kepada kebijakan Kementerian Kesehatan tentang penanggulangan TB Paru melalui Strategi Directly Observed Treatment Short-course (DOTS) 
dalam upaya penemuan penderita TB paru, kebijakan khusus Puskesmas Balai Selasa tidak ada. Upaya menyampaikan kebijakan ini masih belum maksimal, karena masih ada bidan-bidan yang lupa atau tidak paham tentang langkah-langkah mengenai penemuan penderita TB Paru melalui strategi DOTS.

Hasil penelitian didapatkan bahwa SDM yang ada di Puskesmas Balai Selasa sudah mencukupi secara kuantitas, hanya saja koordinator TB Paru masih dibebankan sebagai tenaga medis di ruang pelayanan, sehingga dalam uraian tugasnya koordinator TB Paru memiliki tugas rangkap, hal ini disebabkan dalam perencanaan penempatan tenaga, manajemen puskesmas belum melakukan analisis jabatan yang dapat melihat beban kerja masingmasing penanggung jawab program.

Berdasarkan wawancara mendalam, Bantuan Operasional Kesehatan (BOK) Puskesmas Balai Selasa sudah ada penganggaran untuk program TB Paru. Anggaran yang tersedia sudah mencukupi namun untuk pengalokasiannya belum memprioritaskan pada penemuan penderita TB Paru, karena perencanaan anggaran program TB Paru belum berdasarkan permasalahan yang terjadi yakni rendahnya capaian penemuan kasus TB Paru.

Sarana dan prasarana yang ada di Puskesmas Balai Selasa untuk mendukung penemuan penderita TB Paru adalah adanya ruang pemeriksaan, adanya labor, adanya peralatan pendukung seperti masker, pot sputum. Puskesmas Balai Selasa seharusnya sudah bisa menjadi Puskesmas Rujukan Mandiri (PRM) karena sumber daya manusia sudah memenuhi standar, hanya perlu menambah peralatan mikroskop yang dapat membaca hasil.

Komunikasi penyampaian informasi terkait kebijakan TB Paru diterima dari Pimpinan Puskesmas dan hanya disampaikan kepada Koordinator TB Paru, selanjutnya dari koordinator TB Paru tidak diteruskan kepada bidan-bidan yang juga dilibatkan dalam penemuan penderita TB Paru, hal ini terjadi karena koordinator TB Paru beranggapan informasi tersebut lebih baik disampaikan oleh pimpinan puskesmas sehingga bidan pelaksana mempunyai komitmen yang baik dalam menjalankan kebijakan.
Standar Operasional Prosedur (SOP) TB Paru dan pemeriksaan labor sudah tersedia di puskesmas dan dijadikan acuan dalam melaksanakan kegiatan, namun puskesmas belum memiliki struktur organisasi khusus TB karena manajemen puskesmas memang belum pernah merencanakannya, dan puskesmas juga belum melakukan kerjasama dengan lintas sektor terkait penemuan atau program TB Paru.

Berdasarkan wawancara mendalam dapat diketahui jika perencanaan di Puskesmas Balai Selasa hanya dilakukan dengan membuat perencanaan di awal tahun tahun dan dituangkan dalam Plan of Action (POA), namun perencanaan hanya dibuat ditingkat puskesmas. Perencanaan di tingkat pustu tidak pernah diinstruksikan oleh Kepala Puskesmas untuk membuat POA terkait kegiatan penemuan penderita TB Paru.

Pelaksanaan penemuan penderita TB Paru di Puskesmas belum maksimal, karena penemuan penderita TB Paru berdasarkan pada pasien yang langsung datang ke puskesmas dan terduga TB Paru. Pelacakan kasus hanya dilakukan sekali-sekali dan itupun dilakukan jika ada penderita terduga TB Paru yang tidak mau datang ke puskesmas untuk memeriksakan diri atau melakukan pengobatan.Peran bidan juga belum maksimal dalam penemuan penderita TB karena belum pernah melakukan kunjungan rumah untuk melacak adanya kasus TB di masyarakat Puskesmas Balai Selasa.

Monitoring dan Evaluasi di Puskesmas Balai Selasa belum optimal, karena pimpinan masih melakukan pemantauan berdasarkan laporan dari koordinator TB puskesmas saja. Pemantauan langsung kelapangan dan ke pustu belum dilakukan.Evaluasi untuk menilai pelaksanaan kegiatan penemuan penderita TB belum pernah dilakukan.Kegiatan evaluasi hanya dilakukan saat lokmin di puskesmas, dan itupun tidak secara khusus membahas tentang penemuan penderita TB.

Hasil penelitian didapat bahwa koordinasi antara pemerintahan daerah yaitu camat, tokoh masyarakat dengan puskesmas dalam upaya penemuan penderita TB belum ada, sehingga dukungan dari camat dan tokoh masyarakat belum 
terlihat. Hal ini disebabkan karena puskesmas juga belum pernah melakukan pertemuan dengan pihakpihak tersebut untuk membahas tentang penemuan penderita TB, diharapkan tahun 2020 Puskesmas sudah mulai melakukan koordinasi dan kerjasama melalui pertemuan yang bertujuan membuat komitmen untuk bersama-sama menemukan penderita TB.

Berdasarkan observasi yang dilakukan terhadap lingkungan penderita TB diketahui jika selama ini penderita TB akan menyembunyikan penyakitnya dari lingkungan tempat tinggalnya karena merasa malu, tetapi masih ada penderita TB yang menyadari sendiri jika penyakit TB adalah penyakit yang harus diobat, dan stigma negatif terhadap penderita TB hanya ada masyarakat yang tempat tinggalnya jauh dari akses ke pelayanan kesehatan.

Output dalam implementasi penemuan pasien TB Paru diketahui bahwa masih rendahnya capaian penemuan penderita TB di Puskesmas Balai Selasa disebabkan oleh masih kurang SDM, sarana, biaya dalam menunjang penemuan penderita TB. Dalam pelaksanaan masih kurang optimal karena pelacakan kasus belum dilakukan secara maksimal langsung ke masyarakat, serta belum adanya koordinasi dengan pemerintah daerah dan tokoh masyarakat di Wilayah Puskesmas Balai Selasa, dan adanya rasa malu dari masyarakat untuk memeriksakan diri ke Puskesmas.

\section{PEMBAHASAN}

\section{Input}

1. Kebijakan

Kebijakan merupakan suatu deklarasi mengenai dasar pedoman untuk bertindak, suatu arah tindakan tertentu, suatu program program mengenai aktivitas-aktivitas tertentu atau suatu rencana. ${ }^{14}$ Pemerintah Pusat melalui Kementerian Kesehatan mengeluarkan kebijakan melalui Permenkes RI No 75 Tahun 2014 tentang puskesmas sebagai ujung tombak implementasi pelayanan kesehatan. Puskesmas merupakan fasilitas kesehatan tingkat pertama yang mempunyai tugas melaksanakan kebijakan kesehatan, termasuk kebijakan pengendalian TB. ${ }^{15}$
Kebijakan yang dikeluarkan Kementerian Kesehatan untuk penemuan penderita TB Paru lainnya melalui Strategi DOTS. ${ }^{16}$ Menteri Kesehatan juga mengeluarkan Surat Keputusan NO.HK.02.02/Menkes/52/2015 tentang Rencana Strategis Kementerian Kesehatan Tahun 2015-2019, dan mentapkan target penemuan penderita TB Paru BTA Positif sampai dengan tahun 2019 sebesar 245/100.000 penduduk. ${ }^{17}$ Disamping itu, kebijakan penanggulangan TB Paru lainnya juga dikeluarkan Permenkes No. 67 Tahun 2016 tentang Penanggulangan TB Paru dan dengan adanya kebijakan ini diharapkan target Sustainable Development Goals (SDG's) pada tahun 2030 akan tercapai. $^{18}$

Kebijakan di Puskesmas Balai Selasa yaitu kebijakan masih mengacu kepada kebijakan pusat saja seharusnya kebijakan yang dikeluarkan oleh Kementerian Kesehatan dirasa masih perlu diperkuat dengan kebijakan dari pimpinan Puskesmas Balai Selasa, terkait bagaimana upaya peningkatan capaian penemuan penderita TB Paru dengan mengacu kepada kebijakan nasional. Kebijakan tersebut diharapkan dapat disesuaikan dengan kondisi wilayah Puskesmas Balai Selasa dan mempunyai strategi yang dapat dilaksanakan oleh semua pelaksana kebijakan dalam penemuan penderita TB Paru.

Penelitian Abraham (2018) juga mendapatkan hasil jika faktor yang mempengaruhi terhadap penemuan penderita TB Paru adalah masalah komunikasi, seperti sosialisasi tentang penyakit TB Paru dalam program promosi kesehatan tidak pernah maksimal, tanpa inovasi dan belum menjangkau keseluruh lapisan masyarakat. ${ }^{11}$

Puskesmas memerlukan suatu kebijakan berupa aturan dan mekanisme yang melibatkan staf puskesmas, bidan pustu atau poskesri, dan lintas sektor yang menjadi mitra puskesmas dalam upaya penemuan penderita TB. Pemerintah daerah juga perlu mengeluarkan suatu kebijakan terkait komitmen seluruh pimpinan puskesmas dengan penemuan rendah untuk memprioritaskan kegitan tersebut dengan memperkuat pada internal dan melakukan kerjasama dengan lintas sektor terkait. 


\section{Sumber Daya Manusia}

Tenaga kesehatan merupakan kunci utama dalam keberhasilan pencapaian tujuan pembangunan kesehatan. ${ }^{19}$ Semua tenaga yang terlibat tersebut sudah terlatih atau mengikuti pelatihan terkait program penanggulangan TB Paru baik yang diadakan Dinas Kesehatan Kabupaten Pesisir Selatan ataupun Dinas Kesehatan Provinsi Sumatera Barat.

Sumber daya manusia di Puskesmas Balai Selasa saat ini koordinator TB Paru masih mempunyai tugas rangkap dan manajemen puskesmas belum melibatkan tenaga promkes dalam penemuan penderita TB paru. Pimpinan puskesmas sebaiknya dalam perencanaan penempatan petugas terlebih dahulu melakukan analisis jabatan untuk melihat beban kerja masing-masing jabatan di puskesmas, jika beban kerja suatu jabatan tinggi maka tidak akan bisa jika dibebankan dengan jabatan lainnya. Diharapkan pimpinan puskesmas bisa melibatkan petugas promkes dalam upaya penemuan penderita TB Paru.

\section{Dana}

Ketersediaan dana yang cukup akan menunjang proses kebijakan agar efektif dan efisien, sehingga suatu kebijakan akan menjadi terhambat jika dana yang ada tidak memadai. ${ }^{19}$ Dana dalam pelaksanaan penanggulangan penderita TB Paru di Puskesmas Balai Selasa berasal dari dana Bantuan Operasional Kesehatan (BOK). Meskipun demikian, belum ada anggaran khusus untuk penemuan penderita TB Paru melalui kunjungan rumah dan belum tersedianya dana untuk kegiatan penyuluhan dan sosialisasi khusus yang harus dilaksanakan oleh bidan ataupun koordinator TB Paru.

Penelitian yang dilakukan Ulya dan Thabrany (2017) melalui penghitungan nilai ACER didapatkan bahwa puskesmas dengan metode DOTS mempunyai biaya penyelenggaraan pengobatan TB Paru paling kecil sehingga terbukti puskesmas merupakan yang paling efektif untuk penanganan TB Paru. ${ }^{20}$ Puskesmas sebagai penanggung jawab program di masyarakat hanya membutuhkan biaya Rp 1.948.284 per $1 \%$ kenaikan success rate pasien TB Paru. Hal ini sesuai dengan Permenkes 67 tahun 2016 dimana puskesmas merupakan kepanjangan tangan dari Dinas Kesehatan Kota bertanggung jawab atas pelaksanaan program TB Paru di wilayahnya dengan memanfaatkan jejaring faskes di wilayahnya. ${ }^{18}$

Pimpinan Puskesmas Balai Selasa diharapkan dapat mengatur pembagian alokasi dana program TB dengan lebih memprioritaskan kepada kegiatan penemuan penderita TB secara aktif dan mengurangi volume kegiatan lainnya seperti penguatan Project Management Office karena kegiatan tersebut sudah pernah dilakukan pada tahun sebelumnya, sehingga tidak perlu penambahan anggaran karena anggaran yang dialokasikan saat ini sudah mencukupi.

\section{Sarana dan Prasarana}

Sarana merupakan alat bantu untuk memperlancar dan mempermudah pekerjaan. Dalam dunia usaha untuk mencapai hasil yang lebih baik, selain manusia yang ahli dalam bidangnya, juga dibutuhkan bahan/materi sebagai salah satu sarana. Hal ini disebabkan antara materi dan sarana tidak bisa dipisahkan. ${ }^{21}$

Hasil penelitian yang dilakukan didapat bahwa Puskesmas Balai Selasa termasuk puskesmas satelit dan sudah memiliki sarana dan prasarana sesuai standar. Sarana laboratorium menjadi sarana paling penting dalam penemuan penderita TB Paru, karena dari hasil uji laboratorium dapat ditentukan penderita terdiagnosis TB Paru atau tidak. Untuk meningkatkan kualitas pemeriksaan di puskesmas, bisa diusulkan untuk pengadaan alat yang dapat membaca hasil pemeriksaan sehingga Puskesmas Balai Selasa dapat dijadikan Puskesmas Rujukan Mandiri (PRM).

Penelitian yang dilakukan Awusi et al (2009) menyatakan jika sarana parasana merupakan faktor pendukung yang sangat penting dalam upaya penemuan penderita TB Paru. ${ }^{22}$ Fasilitas TB Paru di Puskesmas berdampak terhadap pelaksanaan penenemuan penderita TB Paru yang dilakukan petugas puskesmas. Penelitian senada juga dilakukan Kasim et al (2012), yang menyatakan jika kendala dalam upaya penemuan penderita TB Paru adalah kelengkapan sarana dan prasarana laboratorium yang dimiliki Puskesmas. ${ }^{23}$ 


\section{Komunikasi dan Struktur Birokrasi}

Komunikasi merupakan salah satu faktor yang mempengaruhi keberhasilan pelaksanaan kebijakan, karena melalui komunikasi terjadi transfer informasi dari pembuat kebijakan kepada pelaksana kebijakan. ${ }^{24}$ Komunikasi merupakan proses penyampaian informasi terkait program TB Paru dalam upaya penemuan penderita TB Paru dari pimpinan puskesmas kepada pelaksana dari penemuan penderita TB Paru tersebut.

Kebijakan yang ada terkait penemuan penderita TB Paru di Puskesmas Balai Selasa belum maksimal, karena kebijakan yang disampaikan dari pimpinan puskesmas hanya sampai kepada koordinator TB Paru puskesmas. Korrdinator TB ini tidak menyampaikan kepada pelaksana lain yang terlibat dalam penemuan penderita TB seperti bidan pustu atau poskesri dan petugas puskesmas lainnya.

Struktur birokrasi penemuan penderita TB Paru terkait SOP dan struktur organisasi, SOP pelaksanaan TB Paru sudah dimiliki oleh Puskesmas Balai Selasa dan dijadikan acuan dalam melaksanakan program TB Paru di Puskesmas Balai Selasa, sedangkan struktur organisasi program TB Paru belum dimiliki puskesmas.

\section{Proses}

\section{Perencanaan}

Terry (2006) menyatakan bahwa perencanaan adalah menyusun kegiatan yang akan dilakukan masa datang dengan memperhatikan sumber daya yang dimiliki untuk mencapai sasaran yang telah ditentukan, sehingga perencanaan dapat mengoptimalkan sumber daya yang dimiliki untuk mencapai tujuan yang diinginkan. ${ }^{24}$

Puskesmas Balai Selasa belum melakukan perencanaan sesuai pedoman disebabkan karena belum adanya instruksi dari pimpinan puskesmas, belum adanya inovasi dan inisiasi puskesmas sebagai pelaksana penemuan penderita TB Paru. Selain itu, puskesmas masih terfokus pada pola pikir lama yaitu pola pikir sentralistik, harusnya puskesmas pola pikir seperti ini ditinggalkan, karena perencanaan itu adalah bottom up planning bukan top down planning.

\section{Pelaksanaan}

Penemuan penderita TB Paru masih belum optimal dalam pelaksanaannya karena komunikasi yang terjalin terkait penemuan penderita TB Paru baru efektif terjalin antara pimpinan puskesmas Balai Selasa dengan koordinator TB Paru puskesmas. Komunikasi terkait pelaksanaan belum terjalin antara pimpinan dengan bidan pelaksana di pustu ataupun poskesri sehingga berakibat kepada kurangnya motivasi bidan dalam melaksanakan penemuan penderita TB.

Kunci keberhasilan program penanggulangan TB Paru adalah dengan menerapkan strategi DOTS. Pemahaman tentang DOTS merupakan hal yang amat penting agar TB Paru dapat ditanggulangi dengan baik.

Penemuan penderita TB Paru menurut Permenkes No 67 Tahun 2014 dilakukan dengan cara pasif dan aktif. Penemuan dengan cara pasif dilakukan dengan pelibatan fasilitas pelayanan kesehatan pemerintah dan swasta, dengan meningkatkan jejaring layanan dan pemeriksaan labor bagi petugas yang datang ke puskesmas. ${ }^{18}$

Penemuan penderita TB Paru secara aktif yang dilakukan di Puskesmas Balai Selasa hanya bila ada instruksi dari Dinas Kesehatan Kabupaten dan Dinas Kesehatan Provinsi, seperti menjalankan program ketuk seribu pintu yang membagikan pot langsung ke rumah-rumah penduduk, namun dalam pelaksanan juga tidak mencapai target karena masyarakat ada yang tidak mengembalikan pot yang diberikan dan petugas pun tidak melakukan sweeping karena terkendala akses rumah penduduk yang jauh.

\section{Monitoring dan Evaluasi}

Monitoring merupakan suatu proses pemantauan yang dilakukan untuk melihat hasil kerja dari suatu kegiatan, sedangkan evaluasi dalam fungsi manajemen, merupakan fungsi penilaian. ${ }^{21}$ Monitoring merupakan pemantauan yang dilakukan secara rutin oleh pimpinan puskesmas atau dinas kesehatan terhadap pelaksanaan penemuan penderita TB Paru di Puskesmas. 
Monitoring semestinya tidak hanya sampai kepada koordinator pengelola TB Paru di puskesmas, tetapi juga harus memonitoring sampai kepada bidanbidan yang ada di Pustu atau Poskesri yang juga ikut dilibatkan dalam penemuan penderita TB Paru. Monitoring yang dilakukan bertujuan untuk melihat sejauh mana pelaksanaan penemuan penderita TB Paru dijalankan, apa saja kendala dan permasalahan yang ditemui yang dapat menghambat tujuan dari capaian penemuan penderita TB Paru di Puskesmas Balai Selasa.

Penelitian Jati dan Sucipto (2006) juga mendapatkan hasil yang sama yaitu jika monitoring dan evaluasi berhubungan dengan cakupan penemuan TB Paru Kabupaten Grobongan Provinsi Jawa Tengah Pada tahun 2003. ${ }^{25}$

Evaluasi dianggap penting dilakukan hanya diakhir tahun saja sebagai bentuk laporan dari capaian program. Sehingga baru diakhir tahun dapat dinilai apakah program berjalan dengan baik atau tidak. Evaluasi semestinya yang dilakukan minimal 3 bulan sekali mampu membuat pimpinan dan koordinator TB Paru melihat kendala-kendala yang ditemui dalam penemuan penderita TB Paru, dan mencari solusi untuk mengatasi hal ini.

\section{Output}

Output dari pelaksanaan penemuan penderita TB Paru di Puskesmas Balai Selasa adalah capaian masih rendah penemuan penderita TB Paru bahkan mengalami penurunan pada dua tahun terakhir. Tahun 2017 capaian penemuan penderita TB Paru hanya mencapai angka 46\% sedangkan target yang ditetapkan adalah $70 \%$. Capaian yang rendah ini disebabkan oleh banyak factor, jika dilihat dari pendekatan sistem yaitu dari kebijakan yang belum tersosialisasikan sampai kepada pelaksana di tingkat bawah sehingga pengetahuan dan pemahaman pelaksana kebijakan masih rendah, sumber daya manusia yang masih mempunyai beban kerja rangkap, dana penemuan penderita TB Paru yang belum ada, serta sarana dan prasarana yang masih belum memadai untuk mendukung penemuan penderita TB.
Pada proses perencanaan yang belum optimal dilakukan terkait penemuan penderita TB Paru, sehingga pelaksanaan hanya sebatas melakukan penemuan secara pasif yaitu jika ada penderita yang langsung datang ke puskesmas. Monitoring dan evaluasi yang kurang dari pimpinan puskesmas dan Dinas kesehatan serta dukungan pemerintah daerah dan tokoh masyarakat dalam menemukan penderita TB Paru, juga menjadi penyebab dari rendahnya penemuan penderita TB Paru di Puskesmas Balai Selasa.

\section{Fakor Eksternal}

Faktor eksternal yang mempengaruhi terhadap capaian dari penemuan penderita TB Paru adalah dukungan dari pemerintah daerah baik pemerintah tingkat kabupaten ataupun pemerintahan kecamatan, karena pemerintah mempunyai daya yang besar dalam memberikan dukungan baik dukungan berupa kebijakan ataupun dukungan dana, namun selama ini Puskesmas Balai Selasa belum melibatkan camat dalam penemuan penderita TB Paru. Hal ini terbukti dari tidak adanya koordinasi antara puskesmas dan kecamatan dalam upaya penemuan penderita TB Paru di Wilayah Puskesmas Balai Selasa.

Peran dari camat dan tokoh masyarakat memiliki pengaruh yang cukup besar terhadap masyarakat, karena camat dan tokoh masyarakat adalah figur yang dihormati dan didengar dan dijadikan panutan oleh masyarakat, oleh karena itu puskesmas perlu membuat rencana pertemuan dengan pihak kecamatan dan tokoh masyarakat untuk membicarakan koordinasi dan kerjasama yang dilakukan dalam upaya penemuan penderita TB Paru di Puskesmas Balai Selasa.

Faktor eksternal lainnya yang mempengaruhi keberhasilan capaian penemuan penderita TB Paru adalah stigma masyarakat, untuk Puskesmas Balai Selasa stigma masyarakat terkait TB paru sudah mulai tidak ada lagi, hanya pada sebagian kelompok saja yang memiliki stigma tersebut. Hal ini disebabkan karena upaya dari petugas kesehatan yang memberikan pemahaman kepada masyarakat 
tentang penyakit TB merupakan penyakit yang dapat diobati. Yang justru menjadi permasalahan eksternal dari capaian penemuan penderita TB Paru dalah rasa malu dari pendrita untuk memeriksakan diri ke puskesmas yang merasa akan dikucilkan jika penyakitnya diketahui oleh masyarakat lainnya. Perasaan malu tadi membuat masyarakat tidak mau mengakui bahkan tidak mau memeriksakan diri ke fasilitas kesehatan.

Tabel 1. Analisis masalah penemuan penderita TB di Puskesmas Balai Selasa

\begin{tabular}{|c|c|c|c|}
\hline No & Masalah & Penyebab & Seharusnya \\
\hline 1 & $\begin{array}{l}\text { Kebijakan belum dipahami oleh } \\
\text { semua petugas yang terlibat dalam } \\
\text { penemuan pasien TB }\end{array}$ & 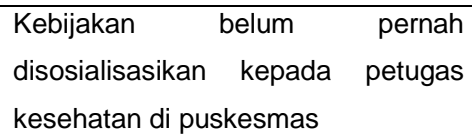 & $\begin{array}{l}\text { Petugas memahami isi dari kebijakan } \\
\text { penemuan penderita TB Paru }\end{array}$ \\
\hline 2 & $\begin{array}{l}\text { Dana yang tersedia } \text { belum } \\
\text { dianggarkan untuk kegiatan } \\
\text { penemuan penderita TB Paru seperti } \\
\text { sweeping }\end{array}$ & $\begin{array}{l}\text { Petugas lebih memprioritaskan } \\
\text { kegiatan TB Paru lainnya sehingga } \\
\text { melupakan kegiatan sweeping } \\
\text { dalam penjaringan suspect }\end{array}$ & $\begin{array}{l}\text { Perlu dianggarakan dana untuk } \\
\text { kegiatan sweeping karena penjaringan } \\
\text { suspect TB Paru selalu dilakukan } \\
\text { setiap tahunnya }\end{array}$ \\
\hline 3 & $\begin{array}{l}\text { Sarana dan prasarana masih kurang } \\
\text { seperti masih belum adanya alat } \\
\text { pemeriksaan dahak di puskesmas }\end{array}$ & $\begin{array}{l}\text { Puskesmas balai selasa belum } \\
\text { dijadikan puskesmas PRM oleh } \\
\text { Dinas kesehatan }\end{array}$ & $\begin{array}{l}\text { Pemeriksaan dahak sudah harus bisa } \\
\text { dilakukan di puskesmas balai selasa } \\
\text { melihat banyaknya pasien yang } \\
\text { terduga TB Paru }\end{array}$ \\
\hline 4 & $\begin{array}{l}\text { Kegiatan penemuan penderita TB } \\
\text { Paru belum dimasukkan kedalam } \\
\text { POA puskesmas }\end{array}$ & $\begin{array}{l}\text { Koordinator TB Paru lebih } \\
\text { memprioritaskan kegiatan TB lain } \\
\text { yang memang sudah rutin dilakukan }\end{array}$ & $\begin{array}{l}\text { Penemuan penderita TB Paru } \\
\text { dimasukkan kedalam perencanaan } \\
\text { karena belum mencapai target di tahun } \\
\text { sebelumnya }\end{array}$ \\
\hline 5 & $\begin{array}{l}\text { Penemuan penderita TB Paru lebih } \\
\text { banyak didalam puskesmas } \\
\text { berdasarkan penderita yang datang } \\
\text { sendiri, sedangkan penjaringan } \\
\text { kelapangan masih kurang }\end{array}$ & $\begin{array}{l}\text { Koordinator TB mempunyai tugas } \\
\text { rangkap, sehingga sulit ke lapangan } \\
\text { karena memprioritaskan kegiatan } \\
\text { didalam gedung dan kurangnya } \\
\text { komitmen bidan pustu/ polindes }\end{array}$ & $\begin{array}{l}\text { Koordinator TB tidak mempunyai } \\
\text { tupoksi lain sehingga bisa fokus } \\
\text { menjalankan program TB Paru } \\
\text { khususnya menjaring suspect TB Paru }\end{array}$ \\
\hline 6 & $\begin{array}{l}\text { Evaluasi terkait penemuan penderita } \\
\text { TB Paru belum pernah dilakukan } \\
\text { ditingkat puskesmas sehingga } \\
\text { pimpinan puskesmas tidak } \\
\text { mengetahui bagaimana pelaksanaan } \\
\text { penemuan penderita TB Paru }\end{array}$ & $\begin{array}{l}\text { Kepala puskesmas melakukan } \\
\text { evaluasi berdasarkan laporan } \\
\text { koordinator TB saja }\end{array}$ & $\begin{array}{l}\text { Evaluasi harusnya dilaksanakan } \\
\text { minimal tiga bulan sekali, sehingga } \\
\text { permasalahan terkait penemuan } \\
\text { penderita TB Paru dapat diketahui dan } \\
\text { dicarikan solusi atau jalan keluarnya }\end{array}$ \\
\hline
\end{tabular}

Adapun solusi dari Tabel 1 diatas adalah perlu dilakukan sosialisasi mengenai kebijakan yang ada kepada semua petugas kesehatan di puskesmas, Pada perencaan di tahun 2020 dialokasikan anggaran untuk kegiatan sweeping dan kegiatan yang mendukung pelaksanaan penjaringan suspect TB Paru. Kepala puskesmas mengusulkan kepada dinas kesehatan untuk menjadikan puskesmas balai selasa sebagai puskesmas PRM dan melengkapi peralatan labor puskesmas. Kepala puskesmas mengistruksikan kepada koordinator TB untuk membuat perencanaan terkait penemuan penderita TB Paru dan menjadikan prioritas ditahun yang akan datang.

\section{SIMPULAN}

Implementasi penemuan pasien TB Paru di Puskesmas Balai Selasa belum berjalan dengan optimal. Hal tersebut dapat dilihat dari capaian penemuan penderita TB Paru di Puskesmas Balai Selasa yang masih rendah yaitu 46\% ditahun 2017 sedangkan target yang ditentukan adalah $70 \%$. Banyak kendala yang ditemukan di lapangan seperti masih adanya tenaga program TB yang mempunyai tugas rangkap dan Masih belum adanya kerjasama dan koordinasi lintas sektor antara puskesmas dengan kecamatan ataupun dengan tokoh masyarakat. 


\section{SARAN}

Pimpinan Puskesmas Balai Selasa disarankan melakukan analisis jabatan sebelum menempatkan petugas pada suatu jabatan, untuk melihat besarnya beban kerja. Puskesmas melakukan advokasi kepada camat agar bisa menjalin kerja sama dalam upaya penemuan penderita TB Paru, dengan melakukan sosialisasi tentang penyakit TB Paru di wilayah kerja Puskesmas Balai Selasa.

\section{UCAPAN TERIMA KASIH}

Terima kasih kepada seluruh pihak yang turut membantu dalam menyelesaikan penelitian ini.

\section{DAFTAR PUSTAKA}

1. World Health Organization (WHO). The end TB strategy and targets for tuberculosis prevention, care and control after. Geneva: WHO; 2015.hlm.52.

2. Kementerian Kesehatan Republik Indonesia (Kemenkes RI). Pusat data dan informasi (Tuberkulosis). Jakarta: Kemenkes RI. 2017. hlm. 91-108.

3. Kemenkes RI. Strategi nasional pengendalian TB. Jakarta: Kemenkes; 2014.hIm.84.

4. Raditya DN. Hubungan karakteristik penderita TB dengan kepatuhan memeriksakan dahak selama pengobatan. Jurnal Epidemiologi. 2015; 3 (2): 122-33.

5. Kemenkes RI. Keputusan menteri kesehatan Republik Indonesia nomor 364/MENKES/SK/ IV/2009 tentang pedoman penanggulangan tuberkolosis (TB). Jakarta: Kemenkes RI; 2017.

6. Kemenkes RI. Survei prevalensi tuberkolosis 2013-2014. Jakarta: Kemenkes; 2015.hlm.66-8.

7. Dinas Kesehatan (Dinkes) Provinsi Sumatera Barat. Laporan tahunan 2016. Padang: Dinkes Provinsi Sumatera Barat. 2016.hlm.35-6.

8. Dinkes Kabupaten Pesisir Selatan. Profil dinas kesehatan kabupaten Pesisir Selatan tahun 2017. Pesisir Selatan: Dinkes Kabupaten Pesisir Selatan. 2017.hlm.21-37.

9. Puskesmas Balai Selasa. Laporan tahunan Puskesmas Balai Selasa. Pesisir Selatan: Puskesmas Balai Selasa. 2017.hlm.9-18.
10. Rosmila T, Anneke S, Ayun S. Analisis faktorfaktor yang berhubungan dengan implementasi penemuan pasien TB paru dalam program penanggulangan TB paru di puskesmas kota Semarang. Jurnal Manajemen Kesehatan Indonesia. 2014; 2(2):1-8.

11. Abraham R. Implementasi kebijakan penanggulangan penyakit tuberkulosis di Puskesmas Kamonji kota Palu. Jurnal Katalogis. 2018;6(5):118-23.

12. Mulyadi D. Studi kebijakan publik dan pelayanan publik. Bandung: Alfabeta; 2017.hlm.34-41.

13. Aboy E. Implementasi program penanggulangan tuberkolosis di puskesmas Kampung Dalam Kota Pontianak. Jurnal Publika. 2013; 2(3):101-7.

14. Subarsono A. Analisis kebijakan publik (konsep, teori, dan aplikasi). Yogyakarta: Pustaka Pelajar; 2011.hlm.30-1.

15. Kemenkes RI. Peraturan menteri kesehatan Republik Indonesia nomor 75 tahun 2014 tentang pusat kesehatan masyarakat (puskesmas). Jakarta: Kemenkes RI; 2014.

16. Kemenkes RI. Pedoman penanggulangan TB di Indonesia. Jakarta: Kemenkes RI; 2011.hlm.5473.

17. Kemenkes RI. Surat Keputusan NO.HK.02.02/ Menkes/52/2015 tentang rencana strategis kementerian kesehatan tahun 2015-2019. Jakarta: Kemenkes RI; 2015.

18. Kemenkes RI. Peraturan menteri kesehatan Republik Indonesia nomor 67 tahun 2016 tentang penanggulangan TB paru. Jakarta: Kemenkes RI; 2016.

19. Koontz H, Cyrill, Heinz W. Manajemen jilid 1. Jakarta: Erlangga;1996.hlm. 28.

20. Ulya F, Thabrany H. Efektivitas biaya strategi DOTS. Program tuberkulosis antara puskesmas dan rumah sakit swasta kota Depok. Jurnal Ekonomi Kesehatan Indonesia. 2017;3(1):109-17.

21. Azwar A. Pengantar administrai kesehatan. Jakarta: Binarupa Aksara; 2010.hlm. 43-67.

22. Awusi, Saleh YD, Hadiwijoyo Y. Faktor-faktor yang mempengaruhi penemuan penderita TB Paru di kota Palu Provinsi Sulawesi Tengah. Berita Kedokteran Masyarakat. 2009; 2(2):1-12. 
23. Kasim F, Soen M, Hendranata KF. Monitoring dan evaluasi pelaksanaan strategi directly observed treatment shortcourse sebagai upaya penanggulangan tuberculosis di puskesmas yang berada dalam lingkup pembinaan dinas kesehatan kabupaten Subang. Jurnal Kebijakan Kesehatan Indonesia. 2012;1(3):134-43.
24. Terry GR. Asas asas manajemen. Bandung: PT Alumni; 2006.hlm.16-24.

25. Jati SP, Sucipto E. Hubungan aspek manajemen petugas tb paru puskesmas dengan cakupan penemuan TB paru di Kabupaten Grobongan. Jurnal Kesehatan Masyarakat. 2006;4(3):23-32. 